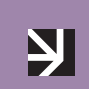

Riikka Juntunen

Lihavan naislaulajuuden muodostuminen musiikkireality-ohjelmissa 
Formations of Fat Female Singer Subjectivities in Reality Television

This article discusses the ways in which fat female singers are presented and present themselves in reality television programmes. Through case studies on Susan Boyle (Britain's Got Talent) and Yoli Mayor (America's Got Talent), I analyse how gender is constructed in the programmes through singing, movement, videography and editing, verbal discussions, and styling. I examine the ideas of fat femininity present in my research material in relation to the conventions of performing fat women in media. Using fat studies, voice studies, and studies of affect and media as my theoretical framework, my aim is to explore what kinds of gender performances are possible for fat female singers in competitive reality television, and how these performances may affect the viewer.

Based on Mayor and Boyle's performances, fat women's gender must be negotiated through discursive, corporeal, and vocal practices in order to be seen as valid. Fatness is framed as a transgression of heteronormative femininity, but its degendering impacts can be mitigated by having an aesthetically pleasing and indisputably feminine singing voice. In terms of affective qualities, fat women are typically seen performing vulnerability and grief. These performances are rewarded by the judges, while performances of aggression are discouraged. While existing in a body that does not conform to media's gendered beauty ideals may enable a contestant to stand out and become memorable to the audience, the singers must conform to the programmes' ideas of acceptable fat femininity in order to advance in the competition. 


\title{
Lihavan naislaulajuuden muodostuminen musiikkireality-ohjelmissa
}

\author{
Riikka Juntunen
}

Tässä artikkelissa tutkin lihavan naislaulajuuden esittämistä analysoimalla kahden laulajan, Susan Boylen ja Yoli Mayorin, esiintymisiä musiikkiesityksiä sisältävissä tosi-tv-kilpailuissa, joista käytän nimitystä musiikkireality. ${ }^{1}$ Tarkastelen erityisesti sitä, miten ohjelmissa esitetään ja tuotetaan naislaulajien ${ }^{2}$ sukupuolta suhteessa ruumiinkokoon muun muassa musiikillisen toiminnan, puvustuksen, kuvauksen ja puheen keinoin. Käytän aineistona Boylen ja Mayorin lauluesityksiä sekä muuta niiden yhteydessä nähtävää audiovisuaalista materiaalia. Hyödynnän kriittisen lihavuustutkimuksen teorioita, lauluesityksen tutkimusta ja affektitutkimusta sen tarkastelemiseen, miten lihavaa naislaulajuutta koetaan ja sen merkityksiä muodostetaan medioituneissa lauluesityksissä. Tosi-tv-tutkimuksen avulla analysoin, miten genren ominaispiirteet ja käytänteet osallistuvat kokemusten ja merkitysten rakentamiseen. Lihavuuden mediaesityksiä koskevan tutkimuksen kautta havainnoin, miten aineistoni suhteutuu lihavan naiseuden esittämisen konventioihin.

Artikkeli perustuu pro gradu -tutkielmaani (Juntunen 2020), jossa käsittelen Boylen ja Mayorin esityksiä laajemmin suhteessa musiikkirealityn tähteyskäsityksiin, affektiivisuuteen, vallankäyttöön ja kehopositiivisuusideologioihin. Tässä artikkelissa keskityn analysoimaan sukupuolen tuottamista Boylen koe-esiintymisessä sekä Mayorin esityksiin liittyvissä

\footnotetext{
1 Tosi-tv (engl. Reality TV) on genrenimike, joka pitää sisällään monenlaisia televisioviihteen muotoja (Holmes ja Jermyn 2004, 2). Aineistoni kaltaisia ohjelmia on tutkimuskirjallisuudessa käsitelty esimerkiksi tapahtumatelevisiona (engl. event $T V$ ) ja kykyrealityina (engl. talent-based reality television) (Holmes ja Jermyn 2004; Barton 2013). Käytän tutkimuksessani termiä musiikkireality, sillä tutkimuskysymysteni kannalta on olennaista tarkastella sitä, miten musiikkiesitys toimii osana kilpailumuotoista tosi-tv:tä ja millaisia tosi-tv-esiintyjyyden muotoja esityksissä syntyy.

2 Käytän artikkelissa termejä "naislaulaja" ja "naislaulajuus" kuvaamaan tapoja, joilla sosiokulttuuriset sukupuoliroolit määrittävät, millaisia toimijuuksia aineistoni laulajille voi ohjelmissa muodostua ja millaisten kulttuuristen normien pohjalta heidän esityksiään rakennetaan ja arvioidaan.
} 
tilanteissa, joissa tunneilmaisun, ruumiillisuuden ja sukupuolen merkitykset ovat erityisen vahvasti esillä.

Susan Boyle esiintyi Britain's Got Talentin kolmannella tuotantokaudella, joka näytettiin televisiossa keväällä 2009, ja Yoli Mayor America's Got Talentin 12. kaudella, joka esitettiin kesällä 2017. Boylen koelaulu herätti laajaa kansainväistä huomiota ja teki hänestä populaarikulttuurisen ilmiön. Jaksoa, jossa koelaulu nähdään, katsoi Britanniassa yli 11 miljoonaa ihmistä (Wilkes 2009), ja internet-videot Boylen koe-esiintymisestä keräsivät yli 85 miljoonaa katselukertaa kymmenessä päivässä (Meizel 2011, 29-30). Boylen koe-esiintyminen on näin noussut kansainvälisesti tunnetuksi esimerkiksi tilanteesta, jossa lihavaan naislaulajuuteen liittyvät asenteet tulevat esiin lauluesityksen kontekstissa. Yoli Mayorin America's Got Talent -uran tarkasteleminen Boylen rinnalla tarjoaa mahdollisuuden havainnoida, miten lihavan naiseuden esittäminen musiikkirealityissa on muuttunut vuosien 2009 ja 2017 välillä.

Ruumisnormit ovat kulttuuri- ja kontekstisidonnaisia, ja käsitys siitä, millainen ruumis on katsomisen ja kuuntelemisen arvoinen, on länsimaissa vaihdellut (ks. Harjunen 2006; Klein 2001; Strings 2019). 1900-luvulta lähtien lihavuutta on stigmatisoitu yhä voimakkaammin liittämällä siihen esimerkiksi uutisissa, taiteessa ja viihteessä mielikuvia laiskuudesta, sairaudesta ja moraalittomuudesta (Harjunen 2006, 184185; Kyrölä 2014, 2). Näin ollen lihavuuden kohtaaminen niin mediassa kuin fyysisesti jaetussa tilassa herättää monenlaisia tunnereaktioita. Lihava nainen esiintyjänä on edelleen harvinainen näky erityisesti siihen nähden, että lääketieteen käyttämillä kriteereillä ylipainoisiksi luokitellaan yhdysvaltalaisista naisista 67 prosenttia (NIH 2014) ja eurooppalaisista 51 prosenttia (WHO 2020). ${ }^{3}$ Lihavia naislaulajia on esimerkiksi oopperan ja bluesin konteksteissa kohdeltu sekä juhlittuina diivoina, joiden ruumiinkoon koetaan osaltaan mahdollistavan poikkeuksellisen voimakkaan lauluäänen tuottamisen ja läsnäolon esiintyjänä, että ruumiillisuudeltaan rappiollisina tai naurettavina (Guarracino 2010; Davis

3 Lääketieteellisissä konteksteissa lihavat henkilöt määritellään ylipainoisiksi tai liikalihaviksi painoindeksin (engl. body mass index, BMI) perusteella. Painoindeksin käyttämistä lihavuuden määrittäjänä on kritisoitu sekä kriittisen lihavuustutkimuksen että lääketieteellisen tutkimuksen piireissä. Se on alun perin populaatiotason muutosten tutkimiseen kehitetty väline, jota ei ole tarkoitettu sovellettavaksi yksilöiden tarkasteluun, eikä sen avulla selville saatava painon ja pituuden suhde kerro mitattavan kehon koostumuksesta tai toiminnasta. Normaalipainon rajojen määrittäminen painoindeksin avulla perustuu dataan, joka ei huomioi riittävästi esimerkiksi sukupuolen ja etnisen taustan merkitystä kehonkoostumuksessa. (Kyrölä \& Harjunen 2007, 16-17; Raisborough 2011, 96-98; Jackson et al. 2002; Eknoyan 2007.) 
1999). Pop-musiikin alalla lihavien naislaulajien näkyvyys on ollut vähäistä (Riihimäki ja Pääkkölä 2020, 194). Adelen suosio on herättänyt 2000-luvulla keskustelua lihavan naislaulajuuden roolista pop-musiikissa, ja 2010-luvulla kansainväliseksi tähdeksi noussut Lizzo on harvoja esimerkkejä laulajista, joiden lihavuus on olennainen osa heidän artistipersoonaansa (ks. Senyonga ja Luna 2021).

Musiikkirealityt tarjoavat mahdollisuuksia lihavien laulajien katsomiseen ja kuuntelemiseen huomattavan paljon verrattuna muihin valtavirtaisen populaarimusiikin konteksteihin. Ohjelmien pyrkimys löytää tähtipotentiaalia "tavallisista ihmisistä" tarkoittaa, että niissä näkyvä ruumiillisuus on monipuolisempaa kuin musiikkiteollisuudessa muuten (Holmes 2004, 151-156). Susan Boyle lienee musiikkirealityissa esiintyneistä lihavista naislaulajista tunnetuin, mutta ei ensimmäinen - Casey Donovan voitti Australian Idolin jo vuonna 2004. Monet sittemmin musiikkirealityihin osallistuneista lihavista naisista ovat esiintyneet omilla tuotantokausillaan vain kerran tai kaksi ennen karsiutumistaan, mutta esimerkiksi Britannian The X Factorissa vuosina 2017 ja 2018 kilpaillut Scarlett Lee lauloi tuotantokausillaan yhteensä lähes 20 esitystä. Yhdysvaltalaisen The Voice -musiikkirealityn 17. tuotantokauden finaalissa vuonna 2019 lihavia naislaulajia nähtiin kaksi, Rose Short ja Katie Kadan. Musiikkirealityn rooli mediana, joka nostaa esiin marginalisoitujen ryhmien edustajia ja tavoittaa laajoja yleisöjä tekee siitä antoisaa analysoitavaa, kun pohditaan, miten lihavan naislaulajuuden mediaesitykset voivat vaikuttaa käsityksiin lihavista naisista yleisemmin (ks. Graham 2017, 19-20).

Tosi-tv-ohjelmien keskeinen toimintalogiikka perustuu voimakkaiden tunteiden esittämiseen ja herättämiseen niin osallistujissa kuin katsojissa (Hesmondhalgh ja Baker 2008, 108; Skeggs ja Wood 2012, 24-25). Tutkimuksessani tarkastelen sitä, miten nämä tunnekokemukset syntyvät ja millaisia vaikutuksia niillä on. Hyödynnän analyyseissani affektin ja affektiivisen kutsun käsitteitä. Affektilla viittaan ruumiilliseen kokemukseen, joka herää suhteessa johonkin ärsykkeeseen ja jonka kokija mahdollisesti merkityksellistää nimettäväksi tunteeksi (ks. Paasonen 2011, 22-23). Affektiivisilla kutsuilla tarkoitan tapoja, joilla ihmisiä ohjataan kohtaamaan kuvia tai audiovisuaalista materiaalia tietyillä kulttuurisesti muotoutuvilla tavoilla ja tiettyjen tunnelatausten kautta (ks. Kyrölä 2014). Audiovisuaalisen median tapa näyttää, korostaa, piilottaa, sanoa ääneen ja jättää sanomatta asioita ohjaa katsoja-kuulijaa reagoimaan tietyllä tavalla ja muodostamaan tietynlaisia affektiivisia suhteita mediaesitysten kanssa (Kyrölä 2014, 1-2). Lauluääni voi olla affektiivisen 
kutsun välittäjänä erityisen vaikuttava, sillä ääni koskettaa kuulijaa ruumiillisella tasolla ja hajottaa käsitystä laulajan ja kuulijan erillisyydestä (Jarman-Ivens 2011, 2-3; Neumark 2010, xix; Tiainen 2013, 387-388). Kutsu sisältää kuitenkin aina mahdollisuuden kieltäytyä ja katsoa tai kuunnella toisin. Se, kuinka vaikutusvaltaiseksi kukin kutsu muodostuu, riippuu katsojan historiasta ja kokemusmaailmasta. (Kyrölä 2014, 1-2.) Tarkastelemani lauluesitykset sisältävät näin ollen potentiaalia sekä rajoittaviin että mahdollistaviin katselu- ja kuuntelukokemuksiin.

Tutkimukseni tavoitteena on tuoda esiin tapoja, joilla lihaviin naisiin kohdistuvat asenteet tulevat ilmi ja muodostuvat televisioiduissa lauluesityksissä, ja pohtia niiden vaikutuksia katsoja-kuulijan kokemuksiin ja käsityksiin ruumiillisuudesta ja sukupuolesta. Sukupuolen merkityksiä neuvotellaan aineistossani esimerkiksi ohjelmistovalintojen, esiintymisasujen, lavaliikehdinnän, esitysten ympärillä käytävien keskustelujen sekä kuvaus- ja ohjausvalintojen keinoin. Näiden lisäksi tarkastelen laulamisen ja lauluäänen merkitystä sukupuolen tuottamisessa suhteessa lihavaan ruumiillisuuteen. Lauluääntä tulkitaan aineistossani ensisijaisesti laulajan todellisen minuuden ilmentymänä (ks. Frith 1996, 185-186, 196-197). Analyyseissani osoitan, että ääni on myös lihavan naiseuden esittämisen keino, jota laulaja voi käyttää yleisön odotusten mukaisesti tai niitä vastaan (ks. Auslander 2006 112-115). Lauluääntä tuotetaan ja vastaanotetaan kulttuurisissa konteksteissa, joiden tarjoamien kategorisointien läpi sen suhdetta laulajan ruumiillisuuteen ja identiteettiin tulkitaan. Ääni on sekä fysiologian ja affektiivisten tilojen että tietoisten ja tiedostamattomien valintojen tuote. Näin ollen laulajan äänessä koettava minuus ei voi olla sosiokulttuurisista vaikuttimista vapaata. (Dame 2006 [1994], 140; Jarman-Ivens 2011, 18-21.)

Käsittelen lihavan naislaulajuuden muotoutumista musiikkirealityssa kahden teeman kautta. Ensimmäinen analyysini keskittyy Susan Boylen koe-esiintymiseen ja siihen, miten Boylen sukupuoli, ihmisyys ja toimijuus muodostuvat marginalisoidun ruumiillisuuden, ihannoidun lauluäänen sekä ruumiinkokoon, ikään ja yhteiskuntaluokkaan liittyvien käsitysten yhteisvaikutuksessa. Toisessa analyysissa tarkastelen Yoli Mayorin esityksiä affektiivisen kutsun näkökulmasta. Pohdin, millaista affektiivista sisältöä Mayoriin liitetään, miten lihava naisruumis valjastetaan surun esittämisen instrumentiksi ja miten nämä esitystavat vaikuttavat esiintyjän ja katsojan välille muodostuvaan suhteeseen. 


\section{Lihavan musiikkireality-esiintyjyyden tutkiminen}

Analysoin Boylen ja Mayorin esityksiä kriittisen lihavuustutkimuksen teorioiden avulla. Kriittinen lihavuustutkimus (engl. fat studies) on humanistis-yhteiskuntatieteellinen tutkimussuuntaus, joka tarkastelee lihavuutta ruumiillisena, sosiaalisena ja kulttuurisena ilmiönä sekä henkilökohtaisena kokemuksena (Harjunen ja Kyrölä 2007, 9-15; Pausé, Wykes ja Murray 2014, 2-3). Historiallisesti lihavuuden tutkiminen on tarkoittanut lääketieteellistä tutkimusta, jossa lihavuutta tarkastellaan terveysongelmana (Kyrölä 2014, 7). Lihavuuden tutkiminen yhteiskunta- ja kulttuuritieteellisin keinoin alkoi vakiintua omaksi tutkimusalakseen 1990-2000-luvun taitteessa (Harjunen 2017, 13). Nykymuotoinen kriittinen lihavuustutkimus ammentaa feministisen ruumiillisuuden ja ruumisnormien tutkimuksen lisäksi queer-tutkimuksesta, vammaistutkimuksesta ja kriittisestä rodun tutkimuksesta (engl. critical race studies) (Harjunen 2017, 14; Solovay ja Rothblum 2009, 2-3). Kriittisellä lihavuustutkimuksella on tiivis yhteys ja yhteinen historia poliittisen aktivismin kanssa, joten tutkimuksella on usein emansipatorisia ja poliittisia tavoitteita (Pausé, Wykes ja Murray 2014, 2-3). Lihavuustutkimus purkaa ajattelutapoja, joissa ruumiinkoko nähdään merkkinä henkilön fyysisestä kyvykkyydestä ja henkisistä ominaisuuksista, sekä kyseenalaistaa käsityksiä normaalista ruumiillisuudesta ja sen asemasta tavoittelemisen arvoisena tilana (Kyrölä 2014, 7). Musiikintutkimuksen piirissä kriittisen lihavuustutkimuksen näkökulmasta on tutkittu esimerkiksi lauluja ja laululyriikoita (Puuronen 2007; Pääkkölä 2017) sekä musiikkivideoita (Pääkkölä 2019; Riihimäki ja Pääkkölä 2020). Analyysissani hyödynnän kriittisen lihavuustutkimuksen näkökulmia sen hahmottamiseen, miten aineistossani tuotetaan lihavaa naislaulajuutta ja miten esitykset suhteutuvat kulttuurisesti vakiintuneisiin tapoihin katsoa, kuunnella ja merkityksellistää lihavaa naiseutta.

Molemmat analyysiesimerkkini ovat peräisin Got Talent -kykykilpailuohjelman tuotannoista. Got Talent on Simon Cowellin perustaman tuotantoyhtiö Syco Entertainmentin omistama formaatti, jonka kansallisia versioita on esitetty kymmenissä maissa vuodesta 2006 alkaen (Syco Entertainment 2020). Ohjelmassa nähtävien kilpailuesitysten sisältö ei rajaudu pelkästään musiikkiin, mutta formaatti noudattaa musiikkireality-genren toimintaperiaatteita. Musiikkirealityt ovat sekä televisiota television tekemisestä että televisiota pop-tähtien tekemisestä (Meizel 2011, 27). Televisio-ohjelman tuotantoprosessit tehdään katsojalle näkyviksi, 
ja keskustelut siitä, mitä esiintyjien tulee tehdä ja millaisia olla saavuttaakseen tähteyden, ovat olennaista sisältöä. Viihdeteollisuuden kaupallisuus on läsnä mainosten, sponsorien ja tuotesijoittelun kautta. Katsojan vaikutusvaltaa korostetaan ja tätä houkutellaan vuorovaikuttamaan ohjelman kanssa erityisesti kilpailijoita äänestämällä. (Meizel 2011, 28-33.) Musiikkirealityt ovat luonteeltaan sekä kansallisia että ylikansallisia (ks. Meizel 2011; Rautiainen-Keskustalo 2013). Sen lisäksi, että formaatteja myydään eri maihin ja paikalliset tuotantoyhtiöt tekevät niistä kansallisia versioita, esitetään varsinkin yhdysvaltaisia ja brittiläisiä versioita formaateista ympäri maailmaa. Lisäksi ohjelmissa nähdyt yksittäiset esitykset kiertävät internetissä esimerkiksi videopalvelu YouTuben välityksellä. Kansallisissa versioissa musiikkirealityn muodot ja merkitykset rakentuvat ylikansallisen formaatin asettamien raamien ja paikallisten kulttuurien kohtaamisissa (Rautiainen-Keskustalo 2013, 331). Omassa analyysissani tarkastelen esityksiä ensisijaisesti osana länsimaista ylikansallista populaarimusiikkikulttuuria, jossa laulajien sukupuolen ja ruumiillisuuden esitykset ja niihin liittyvät merkitykset vuorovaikuttavat toistensa ja yleisöjen kanssa yli kansallisten kontekstien rajojen. ${ }^{4}$

Tutkimusesimerkkini edustavat lihavan naislaulajuuden sisällä kahta monin tavoin toisistaan eroavaa naiseuden esittämisen tapaa. Susan Boyle on BGT-esiintymisensä aikaan 47-vuotias työtön ja perheetön nainen, joka saapuu koelauluihin meikittä ja hiukset pörrössä (BGT 1/3). Yoli Mayor on kilpailukaudellaan 21-vuotias ja koe-esiintymisestä lähtien huolitellun ja tyylikkään näköinen (AGT 1/12). Boylen ja Mayorin erilaisten lähtökohtien ohella tapausesimerkkien välisiä eroja selittää myös ajallinen konteksti - Boyle esiintyi BGT:ssa vuonna 2009, ennen 2010-luvun aikana vähitellen valtavirtaistuneen kehopositiivisuusajattelun yleistymistä viihdeohjelmissa (ks. Sastre 2014). Mayorin AGT-esitykset ovat vuodelta 2017, jolloin ajatus moninaisten kehojen kauneudesta ja naisten voimaantumisesta itseluottamuksen kautta on ollut laajalle yleisölle suunnatussa viihteessä huomattavasti tavanomaisempaa. Seuraavaksi tarkastelen, miten lihaviin naisiin kohdistuvat asenteet tulevat esiin Susan Boylen koe-esiintymisessä ja miten hänen esiintyjyytensä muodostuu sukupuoliroolien, ruumiillisuuden ja lauluäänen yhteisvaikutuksessa.

4 Musiikkirealityjen suhteesta kansallisiin musiikkikulttuureihin ja identiteetteihin ks. Meizel 2011; Rautiainen-Keskustalo 2013; Graham 2017. 


\section{Susan Boyle - lihavan naiseuden merkitykset ulkonäön ja lauluäänen suhteessa}

Musiikkirealityissa kilpailijan ikä, sukupuoli, rotu ja kotipaikka sekä hänestä kerrottava tarina ja hänen esityksiinsä liittyvät taiteelliset valinnat muodostavat hahmon, jonka onnistunut esittäminen määrittää kilpailussa pärjäämistä. Kullakin esiintyjällä on käytettävissään rajallisesti aikaa jäädä yleisön mieleen ja herättää tunnereaktioita, jotka jättävät jäljen. Näin ollen heidän tarinansa ja esiintyjäpersoonansa rakentuvat tyypillisesti muutaman valikoidun piirteen ja elämänkokemuksen varaan. (Graham 2017, 13; Meizel 2011, 153-156; Skeggs ja Wood 2012, 2-3.) Musiikkirealityn kaltaisessa melko konservatiivisessa televisioviihteessä esiintyjän oletettu sukupuoli määrittää vahvasti sitä, miten katsojaa ohjataan suhtautumaan tähän (Ganetz 2011). Vaikka ohjelmat mahdollistavat toisinaan mieskilpailijoille esimerkiksi glam rock -genreen olennaisesti liittyvän sukupuolirooleilla leikittelyn ja camp-estetiikan hyödyntämisen, on naiseuden esittäminen tyypillisesti heteronormatiivista ja naiskilpailijoita homogenisoivaa (Ganetz 2011 410; Meizel 2011, 46-50).

Lihavuuden voidaan kokea häiritsevän binäärisiä sukupuolinormeja loiventamalla mies- ja naistyypillisiksi ymmärrettyjen ruumiillisten piirteiden eroja: lihava nainen ei aina ole keskivertomiestä pienempi eikä välttämättä ruumiinmuodoltaan "naisellinen", kun taas lihavien miesten ruumiin pehmeys ja rintojen erottuminen voidaan nähdä feminisoivina piirteinä (Evans Braziel 2001, 232; Harjunen ja Kyrölä 2007, 11). Mediassa lihavat naiset esitetään usein epäviehättävinä, maskuliinisina ja epäseksuaalisina ja lihavuus täten epäonnistumisena heteronormatiivisen naisihanteen toteuttamisessa (Evans Braziel 2001 231-233; Harjunen 2006, 186-187; Jones 2014, 40-42). Got Talent -formaattiin osallistumiselle ei ole ikärajoja, mikä monipuolistaa ohjelmassa nähtäviä naiseuden esittämisen tapoja verrattuna esimerkiksi Idol-formaattiin, jossa kilpailee yksinomaan nuoria aikuisia. Myös Got Talentissa kuitenkin näkyy heteronormatiivisen naisihanteen hallitsevuus ja ohjelmien pyrkimys esittää naiskilpailijat tyttärinä, äiteinä tai heteroseksuaalisen halun kohteina. Lihavat naiskilpailijat eivät sovi vaivattomasti näihin vakiintuneisiin sukupuolirooleihin.

Omassa aineistossani naiseuden normien haastaminen ja neuvotteleminen tulee selkeästi esiin Susan Boylen esityksissä. Boylea lähestytään tämän koelaulua edeltävässä insertissä inhon ja naurun kautta. Ensimmäinen kuva, joka katsojalle näytetään Boylesta, kuvaa häntä istumassa 
muiden koe-esiintymiseen jonottavien kilpailijoiden kanssa leipää syöden, ilmeisen tietämättömänä siitä, että esiintyy kameralle (BGT 1/3, 0:19). Olennainen affektiivinen ohjausväline alkuinsertissä on musiikki. Alkujuonnon aikana soiva intensiivinen, jännitystä herättävä taustamusiikki muuttuu Boylen näkyviin tullessa kevyeksi, keinahtelevaksi musiikiksi, joka herättää mielleyhtymiä komediallisesta kömpelyydestä ja yksinkertaisuudesta (BGT 1/3, 0:23). Taustamusiikkivalinnalla $B G T$ rakentaa Boylesta enemmän sketsihahmoa kuin vakavasti otettavaa kilpailijaa. Lihavuuden komediallisia esityksiä tutkinut Kyrölä (2014, 93-94) esittää, että nauru voi toimia sekä subjekteja toisiinsa lähentävänä että toisistaan etäännyttävänä voimana, jolla on potentiaalia sekä satuttaa ja rajoittaa että avata uusia toimintamahdollisuuksia. Boylen tapauksessa naurua kutsutaan tavoilla, joihin hän ei itse voi osallistua tai vaikuttaa. Jakson komiikka on siten etäännyttävää ja toiseuttavaa.

Backstage-haastattelussa Boyle keskustelee formaatille tyypilliseen tapaan juontajien kanssa taustastaan ja tulevasta esityksestään (BGT 1/3, 0:25). Boyle viittaa esittelypuheenvuorossaan parisuhteen ja perheen puuttumiseen, mahdolliseen yksinäisyyteen, seksittömyyteen ja työttömyyteen, jotka kaikki ovat kulttuurisesti vakiintuneita tapoja hahmotella lihavana naisena elämisen seurauksia (Harjunen ja Kyrölä 2007, 33-34; Harjunen 2006, 185). ${ }^{5}$ Alkuinsertti tuo esiin ikään ja sukupuoleen liitettyjä normeja - keski-ikäinen nainen, jolla ei ole varsinaista uraa tai heteronormatiivista perhettä, ei herätä mielikuvia menestyjästä. Erityisesti lihavan naiseuden esitysten kontekstissa Boylen tarina voidaan nähdä tyyppiesimerkkinä siitä, mitä seuraa hoikan ruumisnormin rikkomisesta. Insertin perusteella Boyle on kulttuurisesti hyväksyttävän naiseuden kategorian ulkopuolella paitsi ulkonäkönsä myös koko ilmi tulevan elämäntilanteensa puolesta.

Käännekohta Susan Boylen BGT-tarinassa on hetki, jolloin hänen lauluäänensä paljastuu. Boylen saapuminen lavalle saa sekä tuomarit että yleisön pyörittelemään silmiään. Tuomariston puheenjohtaja Simon Cowell haastattelee Boylea tylyyn sävyyn ennen tämän laulun alkua (BGT 1/3, 1:02). Tuomarien ja yleisön halveksuvia ilmeitä näytetään televisiokatsojalle lähikuvissa ja valmistellaan näin mahdollisimman dramaattista yllätystä Boylen laulutaidon tullessa ilmi (BGT 1/3, 1:53). Boylen alkaessa laulaa (BGT 1/3, 2:15) on ensimmäisestä sävelestä lähtien selvää,

\footnotetext{
5 "My name is Susan Boyle, I'm nearly 48. Happily unemployed, but still looking. And I'm going to sing for you on Britain's Got Talent today. [...] At the moment, I'm living alone with my cat who's called Pebbles. But I've never been married. Never been kissed. Oh, shame!"
} 
että hänen laulutaitonsa on eri tasolla kuin esitystä edeltävässä materiaalissa on ohjattu odottamaan. Hänen äänensä on vahva, kiinteä ja sointuva, ja laulaminen on varmaa ja enimmäkseen sävelpuhdasta. Käänne yleisön ja tuomarien suhtautumisessa on jyrkkä ja välitön. Studioyleisö puhkeaa hurrauksiin ja aplodeihin ennen kuin Boyle on ehtinyt laulaa kappaleen ensimmäisen fraasin loppuun. Tuomaristossa Simon Cowellin kulmakarvat kohoavat hämmästyksestä ja Amanda Holdenin suu aukeaa ilahtuneen yllätyksen ilmeeseen. Kulisseista käsin esitystä katsovat juontajat kääntyvät katsomaan kameraan hämmentyneen näköisinä (BGT 1/3, 2:22). Boyle muuttuu rumuudessaan ja epäsopivuudessaan torjuttavasta ihmisestä instrumentiksi, joka välittää haluttavia impulsseja ja intensiteettejä - miellyttävää lauluääntä ja sen kantamia emotionaalisia merkityksiä. Hänen esityksensä saa yleisöltä suosionosoitukset, jotka alkavat ensimmäisestä laulufraasista ja päättyvät vasta kauan kappaleen loputtua. Tuomareiden sanallinen palaute on ylitsevuotavan positiivista (BGT 1/3, 5:00). He kertovat Boylen antaneen heille ja yleisölle ihmeellisen yllätyksen ja todistaneen heidän ennakkoluulonsa vääriksi. Boylen epänormatiivinen ja epäilyttävä ruumiillisuus ei ole ongelma hänen osoitettuaan pystyvänsä tuottamaan mielihyvää äänellään.

Boylen toiseuttaminen pohjaa pitkälti siihen, miten hänen poikkeuksellisuutensa esiintyjänä perustuu hänen tavallisuuteensa ihmisenä. Lihominen - ja ikääntyminen - ovat ruumiillisia prosesseja, jotka koskevat kaikkia ihmisiä tavalla tai toisella (ks. esim. Kyrölä 2007, 52; 2014, 28-29). Useimmilla naisilla on jonkinlainen suhde Boylen kaltaiseen lihavan, keski-ikäisen naisen hahmoon, oli kyse sitten tulevaisuuden uhkakuvasta, hahmosta, joksi muuttumista vastaan taistelee aktiivisesti, tai hahmosta, josta tunnistaa itsensä (ks. Kyrölä 2014, 56). Boylen toiseuttaminen on tarpeellista, koska kuka tahansa nainen voi joutua Boylen asemaan - tulla nähdyksi liian lihavana, liian rumana, liian vanhana ja ei-haluttuna (ks. Raisborough 2011, 112-115). Boylen esittäminen naureskelun kohteena tekee hänestä vähemmän todellisen ihmisen, jonka osaan katsoja voi asettua, ja enemmän fiktiivisen hahmon, jolle voi nauraa turvallisen etäisyyden päästä. Vastenmieliseksi toiseksi merkitseminen on mediassa tyypillinen tapa suhtautua lihaviin ruumiisiin ja ottaa samalla kantaa katsojan kokemukseen omassa ruumiissaan. Katsojaa ohjataan yhtäältä kokemaan turvaa ja helpotusta siinä, ettei ole yhtä torjuttava ja ulos suljettu kuin lihava ihminen, ja toisaalta pitämään ruumistaan kurissa erilaisin toimenpitein välttääkseen tämän kohtalon (Kyrölä 2014, 56, 78; Raisborough 2011, 106-107). 
Boylen asema ei-toivottuna toisena purkautuu tämän lauluäänen avulla. Duffettin $(2011,181)$ mukaan Boylen lauluäänen paljastuminen yleisölle vaikuttaa häneen liitettäviin sukupuoli- ja luokkakonnotaatioihin - Boylen puheenäänessä voimakkaasti kuuluva skottiaksentti loiventuu hänen laulaessaan, ja ääni merkityksellistyy feminiiniseksi. Lauluääni on länsimaisissa musiikkikulttuureissa sukupuoleen liittyvien käsitysten läpäisemä ilmiö (ks. esim. Cusick 1999, 29, 32-34; Frith 1996, 183-202; Jarman-Ivens 2011, 17-21). Vaikka sekä klassisen että populaarimusiikin traditiot tarjoavat monenlaisia esimerkkejä siitä, miten lauluääni ja sukupuoli voivat kohdata ja muotoutua yhdessä monilla epänormatiivisilla tavoilla, on laulajan sukupuolen määritettävyys pelkän kuulohavainnon perusteella normi, josta poikkeaminen herättää tyypillisesti keskustelua ja spekulaatiota laulajan sukupuolesta ja seksuaalisesta suuntautumisesta (Dame 2006 [1994], 139-140; Rey 2018 32-33). Susan Boylen tukeva ja lämmin alttoääni sopii kauniin naisäänen muottiin vaivattomasti. Vaikka Boylen ääni esitetään yllätyksenä, on se kuitenkin riittävän hyvin linjassa tämän ruumiillisuuden kanssa voidakseen tulla koetuksi aitona ja uskottavasti Boylen omana. Esityksen piirteet, joita voidaan pitää amatöörimäisinä, kuten korkeiden äänten ajoittainen kireys ja matalien äänten vaikeudet resonoida selkeinä, vahvistavat autenttista vaikutelmaa entisestään. Koska Boylea ei ole esitelty ammattilaulajana, on odotettavissa ja jopa toivottavaa, että hänen esityksensä ei ole täysin ammattimaisen kuuloinen. Hänen affektiivisessa viehätysvoimassaan olennaista on ohjelman kontekstissa halutun äänen ja epätavallisen ulkonäön vuorovaikutus, jossa lauluesityksestä muodostuu argumentti pop-musiikkikulttuurin pinnallisuutta ja kapeaa naisihannetta vastaan (ks. Auslander 2006, 112-113; Richardson 2012, 258).

Itse äänen ohella sukupuolen onnistunutta normatiivista esitystä vahvistaa kappalevalinta. Boylen koelaulukappale I Dreamed a Dream on alun perin sävelletty Les Misérables -musikaaliin (1985). Musikaalissa kappaleen esittää väkivaltaisen ja misogyynisen yhteiskunnan murjoma köyhä yksinhuoltajaäiti Fantine. Fantinen hahmo edustaa musikaalissa moraalisesti puhdasta naiseutta. Hahmo toimii ensisijaisesti välineenä käsitellä patriarkaalisen yhteiskuntajärjestelmän julmuutta ja musikaalin miespäähenkilön jalomielisyyttä tämän pyrkimyksissä pelastaa Fantine (Wolf 2011, 146). Hahmon asema pohjimmiltaan viattomana, rakastavana ja toiveikkaana naisena, joka murskautuu yhteiskunnan julmuuden uhrina, on ilmeinen myös kappaleen tekstissä, vaikka musikaalin juoni ei olisi kuulijalle tuttu. Kappalevalinnan kautta Susan Boylen puutteellisena, jopa vastenmielisenä esitettävä naiseus kytkeytyy viattoman 
ja kärsivän naisen hahmoon, mikä ohjaa katsomaan ja kuuntelemaan myös Boylea itseään uudesta kulmasta. Boylen lauluääni muodostuu hierarkkisten erojen hajottajaksi. Se tukee kulttuurista kertomusta sisäisestä kauneudesta - ihmisarvosta, joka on olemassa hyljeksitystä ulkokuoresta huolimatta.

Fysiologian näkökulmasta ei ole syytä ajatella, että kulttuuristen estetiikkaihanteiden mukaisen äänen tulisi muodostua ruumisnormien mukaisessa kehossa. Lauluäänen ominaisuuksiin vaikuttavat monet kehon rakenteelliset ominaisuudet, jotka yhdistyvät yksilöllisin tavoin ja joista suuri osa ei näy ulospäin (ks. Tarvainen 2012, 68-70). Monenlaiset kulttuuriset narratiivit ja niiden sovellukset viihdeteollisuudessa ovat kuitenkin muodostaneet vahvoja käsityksiä siitä, mitä ulkonäön ja äänen johdonmukainen yhteys tarkoittaa. Ruumiinkoko, sukupuoli ja viehättävyys esitetään taiteessa ja mediassa olennaisina tekijöinä siinä, millaista ääntä henkilöltä odotetaan (ks. Jarman-Ivens 2011, 8). Tässä rakennelmassa Boylen kaltaisen ihmisen laulutaito voidaan uskottavasti esittää yllätyksenä.

Ajatus ihmisen sisäisen ja ulkoisen todellisuuden ristiriidasta elää vahvana myös tavoissa, joilla lihavuutta käsitellään julkisessa keskustelussa. Erityisesti laihdutustuotteiden mainoksissa ja lihavien naisten laihdutustarinoissa esiintyy usein ajatus "sisäisestä hoikasta naisesta" - naisen todellisesta minästä, joka on vankina lihavan ruumiin sisällä (Cooper 1997, 35; Harjunen 2007, 214; Kent 2001, 130-131; Kyrölä 2014, 72). Lihava ruumiillisuus nähdään omasta itsestä irrallisena painolastina, joka estää elämästä elämää sellaisena kuin sen pitäisi sisäisen minän näkökulmasta olla. Lihavan laulajan esitystä seuraavalle kuulijalle lauluääni voi näiden kulttuuristen kertomusten valossa merkityksellistyä tavaksi kommunikoida aitoa sisäistä minuutta (ks. Frith 1996, 185-186). Naurettavuuden ja inhottavuuden sijaan Susan Boylesta tulee traagisten olosuhteiden uhri - sisäisesti kaunis nainen, joka joutuu kärsimään epäoikeudenmukaista kohtelua ruumiillisuutensa vuoksi. Tässä tulkinnassa Boylen esittämän kappaleen dynaamista huippukohtaa lähelle asettuva fraasi "I had a dream my life would be / so different from this hell I'm living" ${ }^{6}$ kutsuu katsomaan ja kuuntelemaan Boylen elämää menetettyjen mahdollisuuksien sarjana, josta BGT:ssa menestyminen tarjoaa ulospääsyn.

Ääni keinona ilmaista sisäistä minuutta epäsopivan ulkokuoren läpi ja ohi monimutkaistaa lihaviin naisiin kohdistuvaa ohjausta irrottaa "todellinen" minuus omasta ruumiillisuudesta ja kokea lihavuus väliaikaiseksi

\footnotetext{
6 ”Unelmoin, että elämäni olisi aivan erilainen kuin tämä helvetti, jossa elän.”
} 
tilaksi (ks. Harjunen 2007, 214). Laulaminen toimintana hajottaa mieli-ruumis-erottelua: se edellyttää kokonaisvaltaista ruumiillista toimintaa ja yhteistyötä kognitiivisen toiminnanohjauksen sekä kappaleeseen ladattavien tunnemerkitysten kanssa (Frith 1996, 190-192; Tarvainen 2018, 92-93). Ristiriidan rakentaminen Susan Boylen ulkonäön ja äänen välille sekä tavat, joilla Boyle puhuu itsestään myöhemmissä inserteissä, vahvistavat käsitystä siitä, että Boylen hahmottaminen ihmisenä, jonka kaikki ominaisuudet ovat yhdenvertaisia osia hänen naislaulajan identiteettiään, on muille ihmisille vaikeaa (BGT 8/3, 0:30; BGT 13/3, 0:34). Boylen ääni kuitenkin on tämän ruumiin tuottamaa ja siinä mielessä osa tämän ruumiillista olemassaoloa; se ei ole muusta ruumiillisuudesta irrallinen sisäisen minuuden ilmentymä, ei Boylen sisällä vankina olevan kulttuurisesti hyväksyttävän naiseuden ulkoinen manifestaatio. Lisäksi äänen esittäminen muita piirteitä merkittävämpänä todellisen minuuden välittäjänä jättää huomiotta kulttuuriset normit ja niiden puitteissa tehtävät valinnat, jotka vaikuttavat laulutilanteiden muodostumiseen (Jarman-Ivens 2011, 19). Boylen vastaanotto tuskin olisi ollut yhtä ihaileva, jos hänen käyttämäänsä laulutekniikkaa tai koe-esiintymiskappaleensa genreä ei olisi pidetty keski-ikäiselle naiselle sopivana.

Myöhemmissä Boylen BGT-jaksoissa tämän hiukset on värjätty, kulmat muotoiltu ja kasvot meikattu ammattimaisesti. Muokkaukset tekevät hänen naiseudestaan normatiivisempaa ja yksiselitteisempää. Boylen asut semifinaalissa ja finaalissa ovat keski-ikäiselle naiselle turvallisia, pitkähihaisia ja yli polven ulottuvia mekkoja, jotka paljastavat hänen ruumistaan hyvin maltillisesti. Koe-esiintymisen insertissä toiseuden tunnun luomiseksi alleviivatut piirteet pyritään myöhemmissä lähetyksissä neutraloimaan, ja Boylen ulkonäköä muokataan vastaamaan paremmin kulttuurisia käsityksiä lahjakkaasta laulajasta. Narratiivinen muodonmuutos hylkiöstä tähdeksi tuodaan näin näkyviin hänen ruumiinsa pinnassa, ja ristiriidaksi koettua äänen ja ruumiin välistä jännitettä puretaan.

\section{Yoli Mayor - lihava naislaulaja affektiivisena toimijana}

Musiikkireality-esiintyjälle muodostettava hahmo ja tarina rakentuvat vuorovaikutuksessa tämän oman persoonan, taustan ja toiminnan kanssa, mutta hahmon esittämiseen liittyy myös ulkoista kontrollointia sekä avoimesti tuomaroinnin muodossa että kulissien takana, katsojalle näkymättömissä tilanteissa (ks. Grindstaff 2002, 122, 166-167; Hesmondhal- 
gh ja Baker 2008, 108). Affektiiviset kutsut - tavat, joilla katsojaa ohjataan suhtautumaan esiintyjään esimerkiksi kuvauksen, taustamusiikin ja dialogin keinoin - ovat ohjelman tuotannon tapoja välittää esiintyjästä toivotun kaltainen vaikutelma. Affektiivisia kutsuja ei kuitenkaan synny ainoastaan tuotannollisten keinojen kautta, vaan myös esiintyjän omassa toiminnassa. Ohjelman näkökulmasta oikeanlaisten kutsujen esittäminen edellyttää laulajalta monenlaista ruumiillista ja affektiivista työtä.

Musiikkirealityissa esiintyjien aitouden tärkeyttä korostetaan jatkuvasti (Holmes 2004, 156-157; Meizel 2011, 30-31). Populaarimusiikin artistien voidaan tulkita ilmentävän esityksissään sekaisin omaa "todellista" minuuttaan, tuotettua artistipersoonaa ja laulun kertojaminää (Frith 1996, 183-186). Musiikkireality-esiintyjien tilanne eroaa vakiintuneista artisteista sikäli, että ohjelmien keskeistä sisältöä on näyttää, miten laulajan omasta persoonallisuudesta muodostetaan artistipersoona. Vaikka prosessi näytetään ja siitä puhutaan avoimesti, ohjelmat eivät esitä sitä keinotekoisena. Ohjelmien diskursseissa kyse on kilpailijan aidon minuuden esittämisestä tavoilla, jotka puhuttelevat yleisöä. Musiikkireality-esiintyjyyden tarkastelemiseen voidaan soveltaa Auslanderin (2006) ajatusta musiikillisesta persoonasta. Auslanderin mukaan musiikillinen toiminta on itsensä esittämistä sellaisena versiona, joka muodostuu tietyn musiikin tietyssä tilanteessa tapahtuvaa esittämistä varten (ibid., 102). Musiikkirealityissa persoonan muodostaminen on vahvasti tv-tuotannon ohjaamaa: laulajat esittävät itseään, mutta näyttäen ne puolet, jotka ovat tuotannon näkökulmasta toivottuja ja jotka sopivat heistä kerrottavaan tarinaan. Kappalevalintojen ja esitysten tulee ilmentää laulajan persoonaa tavoilla, jotka ovat tuomarien mielestä uskottavia. Ei siis riitä, että esiintyjä tuottaa oikeanlaisia affektiivisia latauksia, vaan niiden tulee myös vaikuttaa autenttisilta.

Aineistossani oikeanlaisen affektiivisen työn ja aitouden vaatimus tulee erityisen selvästi esiin Yoli Mayorin AGT-esityksissä. Toisin kuin Susan Boyle, Mayor esitetään alusta asti varteenotettavana kilpailijana, johon juontaja Tyra Banks suhtautuu koe-esiintymistä edeltävässä haastattelussa erittäin ystävällisesti ja kannustavasti. ${ }^{7}$ Osa lihavaan laulaja-

7 Kuubalais-amerikkalainen Mayor kiinnittyy taustansa puolesta myös erilaisiin ruumisnormatiivisiin diskursseihin kuin Boyle valkoisena brittinä. Latinalaisamerikkalaisia naisia koskevat kauneusihanteet korostavat kurvikkuutta ja erityisesti muodokasta lantiota ja takapuolta (Mendible 2007, 2-3; ks. myös Molinary 2007). Lihavuus ei kuitenkaan ole näidenkään normien mukaista, ja Yhdysvalloissa tarve todistaa vääräksi stereotypia lihavista ja epäviehättävistä latinalaisamerikkalaisista naisista voi entisestään lisätä painetta muokata ruumista valkoisten kauneusihanteiden mukaiseksi (Mendible 2007, 2-3; Rohrleitner 2016). 
ruumiillisuuteen liitettävistä diskursseista ja affektiivisista latauksista on kuitenkin säilynyt Boylen ja Mayorin välillä samoina tullen näkyviin hieman eri tavoin. Keskeinen yhtäläisyys analyysiesimerkkieni välillä liittyy siihen, millaisia tunteita lihavat naiset voivat esittää ja millaisia tunteita heidän on sopivaa herättää katsoja-kuulijassa.

Musiikkirealityissa lihavien naislaulajien yleinen esiintymistapa on laulaa melankolisia pop-balladeja paikallaan seisten. Tämä konventio näkyy paitsi analyysiesimerkeissäni myös useiden muiden musiikkirealityissa esiintyneiden lihavien naislaulajien - esimerkiksi Casey Donovanin, Scarlett Leen ja Michelle McManusin (Pop Idol) - kilpailuohjelmistoissa. Mayorin neljästä kilpailuesityksestä kolme on keskenään hyvin samankaltaisia melankolisia soulpop-balladeja pianosäestyksellä. Mayorin järjestyksessä kolmas esitys, brittiartisti Rag'n'Bone Manin synkkä bluesrock-kappale Human, on ainoa, joka ei saa tuomareilta innostunutta vastaanottoa. Mayorin esityksissä ja tuomarien reaktioissa muodostuu järjestelmä, jossa Mayoria kiitetään johdonmukaisesti haavoittuvuuden ja surun esittämisestä ja moititaan aggressiivisen tunnelatauksen välittämisestä.

Lihavuuden ja haavoittuvuuden yhteys on lihavuuden mediaesityksissä alati läsnä, mutta sen käsittely ei tyypillisesti ole yhtä näkyvää kuin pelon, inhon ja häpeän kaltaisten tunteiden (ks. Kyrölä 2014). Surullisuus ja arkuus ovat kuitenkin tyypillisiä tunnelatauksia lihavien hahmojen esittämisessä: lihava ihminen on kohtaamansa syrjinnän seurauksena tai sen pelossa epävarma, ulkopuolinen ja ujo (ks. Cooper 1997, 34). Nämä teemat tulevat ilmi myös Mayorin esitysten inserteissä, joissa hän kertoo joutuneensa toistuvasti kiusatuksi ja ohitetuksi lihavuutensa perusteella (AGT 1/12, 00:15:40; AGT 9/12, 1:09:47). Tarinoitaan kertomalla Mayor purkaa kokemuksiin liittyvää häpeää ja antaa katsojalle mahdollisuuden ymmärtää omia mahdollisia syrjintäkokemuksiaan jaettuna, rakenteellisena ongelmana (vrt. Ahmed 2014, 172). Surun ja nöyryytyksen tunteiden käsitteleminen julkisella foorumilla on kuitenkin vaativaa affektiivista työtä, ja katsojan on mahdotonta tietää, missä määrin Mayor voi itse määrittää sille rajoja (ks. Grindstaff 2002, 122, 166-167; Hesmondhalgh ja Baker 2008, 108).

Mayorin toisen esityksen (AGT 9/12, 1:12:57) kappale, Rihannan Love on the Brain, kertoo tekstin tasolla intensiivisestä, jopa väkivaltaisesta, rakastumisesta ja kaiken nielevästä himosta. Alkuperäisesityksessä Rihannan äänenkäyttö on monipuolista ja leikittelevää. Laulutapa vaihtelee vuotoisesta ja ohuesta soinnista tiiviiseen ja voimakkaaseen soul-laulantaan. Rihanna koristelee esitystään runsailla korukuvioilla, huokauksilla 
ja huudahduksilla. Yleisvaikutelma muodostuu leikkisäksi, myrskyisäksi ja voimakkaan seksuaaliseksi. Mayor laulaa kappaleen pianon säestämänä paikallaan seisten, pitkälti silmät kiinni. Hänen äänensä on voimakas, puhdas ja tummasävyinen. Mayor laulaa kappaleen intensiivisesti, nojaten pitkiin säveliin. Esityksessä on jonkin verran dynaamista vaihtelua äänenvoimakkuudessa ja tiiviydessä, mutta Rihannan esityksen kaltainen keveys ei missään vaiheessa ole läsnä. Mayor on hymytön, rypistää kulmiaan ja vie käsiään nyrkkiin. Ilmeet ja kehonkieli voimistavat kappaleen tekstin epätoivoa ja ahdistusta. Esitys saa seisovat aplodit ja ylistävän palautteen tuomaristolta. Heidi Klum sanoo rakastavansa Mayoria ja pitävänsä tätä yhtenä parhaista, ellei parhaana kilpailun laulajista (AGT 9/12, 1:15:23).

Poikkeuksen Mayorin ylistettyyn musiikilliseen linjaan tekee hänen kolmas kilpailuesityksensä (AGT 13/12). Human-kappale on aiempaa ohjelmistoa raskaampi ja aggressiivisempi. Sen teksti käsittelee voimattomuuden ja turhautumisen tunteita. Mayor esiintyy rockbändin säestämänä dramaattisessa valaistuksessa. Laulumelodia kulkee säkeistössä matalalla, ja Mayorin äänenkäyttö on pehmeää ja hillittyä. Korkeammalla soivassa kertosäkeessä Mayor laulaa voimakkaasti ja intensiivisesti. Hän käyttää tehokeinoina melodiasävelille liukumista hitaasti alakautta, huudahduksenomaista laulua ja äänen säröttämistä, mikä luo vaikutelman raa'asta fyysisestä voimankäytöstä ja pidäkkeettömyydestä. Mayorin kehonkieli välittää jännitteistä latausta samankaltaisilla keinoilla kuin Love on the Brainissa, mutta ilmeiden ja eleiden erilainen konteksti muuttaa myös niiden merkityksiä. Yhdistettynä massiivisempaan säestykseen, näyttävämpään lavatuotantoon ja ennen kaikkea aggressiivisempaan äänenkäyttöön Mayorin ruumiillisuus ei enää kerro hauraasta kärsimyksestä vaan uhmasta, jopa vihasta. Lauluääni mediumina on intiimi ja intensiivinen - Mayorin esitys vaatii kuulijan huomion ja tunkeutuu tähän ruumiillisella tasolla (vrt. Jarman-Ivens 2011, 10-11).

Tuomarit eivät ole esityksestä yhtä vaikuttuneita kuin aiemmista. Heidän kommenttiensa mukaan esityksessä ei näkynyt Mayorin "minuutta" (AGT 13/12, 1:09:43) ja se oli niin ylituotettu, että Mayorin persoona hautautui muiden elementtien alle (AGT 13/12, 1:10:45). Mayorin esityksessä kappaleen laulumelodian matalimmat sävelet kuulostavat hieman työläiltä ja äänenhallinnan vaikeudet kuuluvat ajoittaisena alavireisyytenä, mutta tuomarit eivät mainitse teknisiä piirteitä lainkaan. Kriittistenkin kommenttien yhteydessä Mayorin laulutaitoa ylistetään. Palaute kohdistuu nimenomaan siihen, miten Mayor esityksellä edustaa tai ei edusta 
"omaa itseään". ${ }^{8}$ Tuomarit eivät suoraan puutu esityksen emotionaalisiin ulottuvuuksiin vaan sanovat, etteivät saaneet Mayoriin yhteyttä esiintyjänä ja että tämän aitous ja särmikkyys katosivat.

Tunneilmaisun ja aitouden suhde musiikkirealityissa on jännitteinen. Tosi-tv:ssä kontrollin menettäminen ja tunteiden valtaan näkyvästi antautuminen on ohjelman dramaturgian huippuhetki, jonka saavuttamiseksi tehdään työtä sekä televisionkatsojalle näkyvillä että näkymättömillä tavoilla (Grindstaff 2002, 19-20, 166-167; Aslama ja Pantti 2006, 170). Arjessa yksityisiksi miellettyjen tunteiden näyttäminen julkisessa yhteydessä toimii todisteena siitä, että tosi-tv näyttää jotakin aitoa (Aslama ja Pantti 2006, 177-178). Toisaalta erityisesti kilpailumuotoisessa tosi-tv:ssä liiallinen tai vääränlainen tunneilmaisu voi vähentää kilpailijan uskottavuutta osaajana ja saada katsojan pois tämän puolelta, mikä vaikeuttaa kilpailussa etenemistä (ibid., 171). Mayorin esitykset ja niistä käytävät keskustelut tuovat esiin tunneilmaisun ja autenttisuuden merkitysten neuvottelua. Surun näyttäminen merkityksellistetään tuomarien puheissa rohkeaksi aitoudeksi, viha ja aggressio taas esiintyjän ja yleisen välisen yhteyden katkaisemiseksi. Auslander (2006, 114-115) toteaa musiikillisen persoonan syntyvän vuorovaikutuksessa yleisöjen kanssa. Kun persoona on muodostunut, siltä odotetaan useimmissa tapauksissa johdonmukaisuutta (ibid., 113). Mayorin yritys näyttää toisenlaista musiikillisen persoonansa puolta on tuomarien näkökulmasta yritys muuttaa laulajan ja yleisön välisen suhteen laatua, mikä koetaan epämiellyttävänä.

Mayorin AGT:ssa viimeiseksi jäänyttä semifinaaliesitystä edeltävässä insertissä (AGT 19/12, 0:02:05) hän selittää Human-esityksen saamaa reaktiota omalla itseluottamuksen puutteellaan - hän sanoo olleensa niin hermostunut, että haki turvaa kauniista esiintymisasusta aitouden kustannuksella. Insertissä Mayorin puheen seurana on hidastettua videomateriaalia, jossa hän kävelee Humanissa käyttämässään asussa kohti peiliä. Silmämeikki on valunut poskille kuin kyynelten levittämänä, viitaten surun esittämiseen ja itkuun murtumiseen autenttisuuden todisteina (ks. Aslama ja Pantti 2006, 170). Mayor pesee meikin pois, poistaa irtoripset ja riisuu kaulakorunsa. Samalla hän selittää ääniraidalla: ”Tänä iltana karsin esityksestäni kaiken ylimääräisen. Ei ole mitään, minkä taakse piiloutua." (AGT 19/12, 0:03:33.) Insertti päättyy kuvaan Mayorista kat-

\footnotetext{
8 Myös Graham (2017, 16-17) osoittaa, että karisman ja kiinnostavan esiintyjyyden pitäminen laulusuorituksen teknisiä piirteitä tärkeämpinä sekä näiden seikkojen ensisijaisuus tuomaripalautteissa on musiikkirealityissa tavallista.

9 "I'm stripping back my performance tonight. There's nothing to hide behind."
} 
somassa hymyillen peilistä meikittömiä - tai ainakin aiempaa vähemmän meikattuja - kasvojaan.

Say You Won't Let Go -esityksessä Mayor on kuitenkin meikattu samaan tapaan kuin aiemmissakin jaksoissa, hänellä on päällään juhlava mekko, joskin hieman lyhyempi kuin Humanissa nähty, ja korkokengät ovat vaihtuneet tennareihin (AGT 19/12, 0:03:52). Humaniin verrattuna karsintaa on tehty ennen kaikkea musiikillisesti: Mayor palaa pianosäestykseen. Musiikillisesti Say You Won't Let Go on haikea ja pehmeä popkappale. Mayorin äänenkäyttö on lempeää lukuun ottamatta viimeistä kertosäettä, jossa hän hyödyntää aiemmista esityksistä tuttua melodian koristelua ja voimakkaalla paineella tuotettuja ylä-ääniä. Surun ja haurauden vaikutelma rakentuu samanlaiseksi kuin Love on the Brainissa. Tuomarien reaktio on yksimielisen ylistävä. Mayoria kehutaan juurilleen palaamisesta, esityksen pelkistämisestä ja tunteiden avoimesta näyttämisestä (AGT 19/12, 0:07:00). Tuomari Heidi Klum toteaa: "Tunteiden herättäminen ihmisissä on tismalleen sitä, mitä laulajan tulee tehdä, ja sinä teit juuri niin. Todella teit sen, minulla tuli kyynel silmään. Se oli hyvin tunteikasta."10 (AGT 19/12, 0:07:19.) Haikeiden tunteiden tuottaminen määritellään osaksi Mayorin musiikillista persoonaa: Mayor koetaan aitona ja uskottavana, kun hän tuottaa näitä impulsseja (ks. Auslander 2006, 112-113). Mayorin ruumiillisuuden tuottama nautinto liitetään sen kykyyn herättää liikuttuneisuutta.

Mayoriin ja hänen esityksiinsä liittyvät affektiiviset lataukset edustavat mediassa uudehkoa tapaa esittää lihavaa naiseutta. Lihavan laulajan välittämästä tuskasta vaikuttuminen edellyttää vähintään myötätunnon kokemista, jopa samastumista tähän. Ei-lihavalle katsojalle Mayorin esitykset voivat toimia lihavia ihmisiä inhimillistävinä. Lihavalle katsojalle Mayorin kaari ohjelmassa voi olla arvokasta, ja edelleen valitettavan harvinaista, representaatiota lihavasta naisesta toteuttamassa unelmiaan, esiintymässä samastuttavana ja kiinnostavana hahmona sekä saamassa menestystä ja tunnustusta ympäristöltään. On kuitenkin tärkeää kysyä, miten lihavan katsojan kokemukseen itsestään ja maailmasta vaikuttaa nähdä lihavat ruumiit toistuvasti traagisina. Surua painottavat esitykset voivat entisestään vahvistaa käsitystä lihavuudesta kokemuksena, jota on sopivaa ymmärtää ja kommunikoida muille ihmisille vain kärsimisen kautta. Vammaisuuden esityksiä valokuva-aineistossa tutkinut Rosemarie

10 "Making people feel emotions is exactly what a singer is supposed to do and you just did that. You really did, I mean you brought a little tear in my eye. It was very, very emotional." 
Garland-Thomson (2001, 340) osoittaa, että hänen analysoimiaan kuvia ei ole tehty ensisijaisesti vammaisia katsojia varten vaan että niiden ilmaisutavat palvelevat tavalla tai toisella ei-vammaista katsojaa ja auttavat häntä neuvottelemaan omaa suhdettaan vammaiseen ruumiillisuuteen. Tämän ymmärryksen läpi voidaan katsoa myös lihavuuden mediaesityksiä: mitä tarkoitusta lihavan ruumiin asettaminen tuskan instrumentiksi palvelee ei-lihavalle katsojalle?

Mayorin esittämä suru on estetisoitua sekä visuaalisesti että äänellisesti; kuten melankolinen musiikki yleensä, se mahdollistaa katsojakuulijalle kipeiden tunteiden käsittelyn mielihyvän kautta, turvallisesti. Hänen lauluäänensä on vahva ja miellyttävä, ja tuomarien kehumissa esityksissä se koskettaa tavoilla, jotka on helppo ottaa vastaan ja hyväksyä. Mayorin surun esityksen kokeminen ei haasta kuulijaansa, sillä se on hyvin linjassa inserteissä vakiinnutetun surullisen lihavan tytön narratiivin kanssa. Esitysten visuaalinen ja musiikillinen miellyttävyys synnyttää myös turvaa tuovan vaikutelman kontrollista ja etäisyydestä.

Syrjintäkokemusten ja niiden aiheuttamien traumojen käsittely mediassa ja taiteessa voi olla erittäin tarpeellista. Haluan kuitenkin kysyä, mitä jää lihavuuden mediaesitysten ulkopuolelle, jos niiden luoma tila annetaan ensisijaisesti surulle. Sara Ahmedin (2014, 174) mukaan syrjinnän aiheuttaman tuskan muuttaminen toiminnaksi edellyttää vihaa, joka nousee sen ymmärtämisestä, että oma kärsimys on seurausta epäoikeudenmukaisesta tilanteesta, joka ei voi jatkua. Viha luo vastarintaan vaadittavaa energiaa ja mahdollistaa toisenlaisen tulevaisuuden rakentamisen. Vihaan liittyvä affektiivinen ja ruumiillinen epämukavuus ajaa muutokseen, toisenlaisten ruumiillisten toimijuuksien muodostamiseen. (Ibid., 174-175.) AGT:n lihavuusrepresentaation poliittisen vaikuttavuuden rajat tulevat näkyviin siinä, miten ohjelma lannistaa Mayorin yrityksen liikkua surun ja vihan välillä. Vihan esitysten rohkaiseminen näyttäisi Mayorin voimaantuneena toimijana, joka ei ole riippuvainen tuomariston hyväksynnästä. Lihavan naisen vihan näyttäminen voi myös avata väyliä pohtia sitä, mistä viha tulee ja mihin se kohdistuu. Tässä keskustelussa AGT:n kaltaisten massaviihdeteollisuuden edustajien vastuuta ei voi ohittaa, eikä tällainen itsekriittisyys liene viihdeohjelman kontekstissa mahdollista. 


\section{Lopuksi}

Lihavuuteen kulttuurissamme liitettävät mielleyhtymät vaikuttavat naislaulajien toimijuuteen musiikkirealityissa monin tavoin. Susan Boylen tapauksessa esiin nousevat erityisesti käsitykset siitä, että epämiellyttävänä esitettävä ulkonäkö ymmärretään helposti merkkinä ihmisen arvottomuudesta. Kun lauluääni esitetään sisäisen minuuden ilmentymänä, voi kaunis ja sukupuolinormin mukaiseksi tulkittava ääni inhimillistää ulkonäkönsä perusteella marginalisoitua laulajaa kuulijalle. Yoli Mayorin tapauksessa ohjelmaformaatin puitteissa tapahtuva suora ja epäsuora vallankäyttö lukitsevat hänet esittämään tunteita, joiden koetaan sopivan lihavalle naiselle. Mayorin sukupuoli ja ruumiinkoko vaikuttavat olennaisesti siihen, millaista affektiivista työtä häneltä odotetaan ja vaaditaan.

Ohjelmat voivat hyödyntää ulkonäköön perustuvaa marginalisointia hakiessaan dramaattisia käänteitä, joiden affektiivinen vaikutus katsojaan on mahdollisimman voimakas ja täten ohjelman seuraamiseen aktivoiva ja sitouttava. Kilpailussa eteneminen edellyttää kuitenkin naislaulajan tuomista niin lähelle heteronormatiivista sukupuolen esittämistä kuin tämän ruumiillisuuden puitteissa on mahdollista. Ulkonäön ohella normi koskee myös laulettavaa ohjelmistoa, lauluäänen käyttöä ja tunteiden ilmaisemista. Lihavia naisia koskevat käsitykset siitä, millainen naiseuden esittäminen on ohjelmissa sopivaa ja toivottavaa, liittyvät vahvasti kulttuurisiin käsityksiin lihavista naisista epävarmoina, ulkopuolisina ja epäseksuaalisina. Populaarimusiikin estetiikassa lihava ruumiillisuus on mahdollista ymmärtää merkkinä kaupallisten ulkonäkö-ja sukupuolinormien torjumisesta, autenttisuudesta ja vallasta (ks. Riihimäki ja Pääkkölä 2020, 195). Omassa aineistossani sukupuolinormien rikkomiseen ei lihavilla naislaulajilla ole juuri tilaa, vaan lihavan ruumiillisuuden ja normatiivisen naisellisuuden suhdetta pyritään neuvottelemaan niin, että ne on mahdollista sovittaa yhteen laajoja yleisöjä provosoimatta.

Tutkimukseni on ehdotus siitä, miten lihavien naislaulajien esityksiä musiikkirealityissa voidaan tarkastella osana lihavan naiseuden mediaesitysten laajempaa joukkoa ja hahmottaa, miten nämä esitykset toistavat ja kyseenalaistavat genren konventioita. Pienellä aineistolla tehtyyn tapaustutkimukseen perustuvina johtopäätökseni eivät ole laajasti yleistettävissä. Lihavan naislaulajuuden kategorian sisällä on lisäksi paljon erilaisia ruumiillisuuksia ja identiteettejä, jotka eivät tule aineistossani esiin. Esimerkiksi lihavien mustien naislaulajien, kuten Frenchie Davisin (American Idol) ja Panda Rossin (The X Factor), esityksiin liittyy eri- 
tyinen merkityskenttä verrattuna valkoiseen Boyleen tai kuubalaistaustaiseen Mayoriin. Analyysiesimerkkini kuitenkin havainnollistavat sitä, millainen tapa esittää lihavaa naiseutta on ollut ohjelmien tekohetkellä mahdollinen valtavirtamediassa. Lihavia ihmisiä näkyy esiintyjinä suhteellisen vähän, jolloin yksittäiset tapaukset voivat muodostua merkitykseltään suuriksi siinä, miten katsoja-kuulija muodostaa käsitystä lihavana ihmisenä elämisestä.

Musiikkirealityt ovat kaupallisia toimijoita, joiden menestys riippuu yleisösuosiosta ja mainostajien kiinnostuksesta. Tällöin ohjelmille olisi taloudellinen riski ottaa kantaa tavoilla, jotka voivat provosoida - esimerkiksi tuomalla esiin viihdeteollisuuden ruumisnormien ja laihdutus-, kosmetiikka- ja muotiteollisuuden välisiä yhteyksiä, esittämällä lihavien syrjintä ongelmana, joka vaatii toimintaa muiltakin kuin lihavilta ihmisiltä, tai näyttämällä lihavien naisten kielletympiä tunteita, kuten vihaa ja seksuaalista halua. Formaattien luonne ei mahdollista esityksiä, jotka purkaisivat ruumisnormeja ja niiden ylläpitämiseen liittyvää väkivaltaa eksplisiittisesti, mutta ne voivat tuoda lihavia naislaulajia yleisön tietoisuuteen ja herättää keskustelua siitä, miksi heitä ei pop-artistien joukossa juuri näy. Esimerkkieni perusteella voi myös todeta ohjelmien toimivan vuorovaikutuksessa yhteiskunnallisten keskustelujen kanssa, joten voi myös olettaa ohjelmien lihavuusesitysten muuttuvan monipuolisemmiksi sitä mukaa kuin lisää lihavia esiintyjiä murtautuu viihdeteollisuuden valtavirtaan muissa yhteyksissä.

Kun kulttuuri- tai mediatuote sitoutuu välittämään tiettyä rajattua käsitystä lihavuuden kokemuksesta, se jättää aina ulkopuolelleen monia tarinoita, jotka ovat yhtä tosia kuin kerrottavaksi valikoitunut. Kun lihavista naislaulajista kerrottavat tarinat kietoutuvat ulkopuolisuuden ja surun ympärille, jää lihavaan ruumiillisuuteen liittyvä ilo ja mielihyvä helposti sivuun. Lihavuus esitetään usein uhkana ja sellaisena ruumiillisuutena, jota tulee välttää (ks. esim. Kyrölä 2007; Raisborough 2011), jolloin lihavuuden ja nautinnon yhdistäminen herättää helposti moraalittomia ja likaisia mielikuvia. Kuitenkin lihavan ruumiillisuuden tuottaman mielihyvän esittäminen mediassa elämyksinä, joiden syntyminen edellyttää lihavaa ruumiillisuutta - ei jonakin, jossa laulaja onnistuu lihavuudestaan huolimatta - voisi osaltaan horjuttaa rajoittavien ruumis- ja sukupuolinormien valtaa kaikenkokoisten katsoja-kuulijoiden elämässä. 


\section{Lähteet}

\section{Tutkimusaineisto}

Susan Boyle

Koe-esiintyminen, Britain's Got Talent, 3. tuotantokausi, 1. jakso (BGT 1/3) (videotallenne). Tark. 29.5.2021. https://www.youtube.com/watch?v=jca p 3FcWA.

Semifinaali, Britain's Got Talent, 3. tuotantokausi, 8. jakso (BGT 8/3) (videotallenne). Tark. 29.5.2021. https://www.youtube.com/watch?v=A2XEmMg2HEd.

Finaali, Britain's Got Talent, 3. tuotantokausi, 13. jakso (BGT 13/3) (videotallenne). Tark. 29.5.2021. https://www.youtube.com/watch?v=-fLsTmzRE3M\&t=316s.

Tuloslähetys, Britain's Got Talent, 3. tuotantokausi, 14. jakso (BGT 14/3) (videotallenne). Tark. 29.5.2021. https://www.youtube.com/watch?v=rRSruPOwFrd.

Yoli Mayor

Koe-esiintyminen, America's Got Talent, 12. tuotantokausi, 1. jakso (AGT 1/12) (videotallenne). Tark. 29.5.2021. https://the123movies.stream/series/24386-americas-got-talent/seasons/12/episodes/1.

Judge Cuts, America's Got Talent, 12. tuotantokausi, 9. jakso (AGT 9/12) (videotallenne). Tark. 29.5.2021. https://thel23movies.stream/series/24386-americas-got-talent seasons/12/episodes/9.

Livelähetys,America’s GotTalent, 12.tuotantokausi, 13.jakso(AGT 13/12)(videotallenne). Tark. 29.5.2021. https://the123movies.stream/series/24386-americas-got-talent/seasons/12/episodes/13.

Semifinaali,America's Got Talent, 12.tuotantokausi, 19.jakso(AGT 19/12)(videotallenne). Tark. 29.5.2021. https://the123movies.stream/series/24386-americas-got-talent/seasons/12/episodes/19.

\section{Kirjallisuus}

Ahmed, Sara. 2014. Cultural Politics of Emotion. Edinburgh: Edinburgh University Press.

Aslama, Minna ja Mervi Pantti. 2006. ”Talking Alone: Reality TV, Emotions and Authenticity". European Journal of Cultural Studies 9 (2): 167-184. https://doi.org/10.117 7/1367549406063162

Auslander, Philip. 2006. ”Musical Personae”. TDR: The Drama Review 50 (1): 100119. https://doi.org/10.1162/105420406776092313

Auslander, Philip. 2008. Liveness: Performance in a Mediatized Culture. New York: Routledge. https://doi.org/10.4324/9780203938133

Barton, Kristin M. 2013. "Why We Watch Them Sing and Dance: The Uses and

Gratifications of Talent-Based Reality Television". Communication Quarterly 61 (2): 217-235. https://doi.org/10.1080/01463373.2012.751437

Cooper, Charlotte. 1997. "Can a Fat Woman Call Herself Disabled?" Disability $\mathcal{E}^{\circ}$ Society 12 (1): 31-41. https://doi.org/10.1080/09687599727443

Cusick, Suzanne G. 1999. "On Musical Performances of Gender and Sex". Teoksessa Audible Traces: Gender, Identity, and Music, toim. Elaine Barkin ja Lydia Hamessley, 25-48. Zürich: Carciofoli Verlagshaus. 
Dame, Joke. 2006 [1994]. "Unveiled Voices: Sexual Difference and the Castrato". Teoksessa Queering the Pitch: The New Gay and Lesbian Musicology, toim. Philip Brett, Elizabeth Wood ja Gary C. Thomas, 139-153. 2. painos. New York: Routledge. https:// doi.org/10.4324/9780203944189

Davis, Angela Y. 1999. Blues Legacies and Black Feminism. New York: Pantheon.

Duffett, Mark. 2011. "Elvis Presley and Susan Boyle: Bodies of Controversy". Journal of Popular Music Studies 23 (2): 166-189. https://doi.org/ 10.1111/j.1533-1598.2011.01278. 日

Eknoyan, Garabed. 2008. "Adolphe Quetelet (1796-1874): The Average Man and Indices of Obesity". Nephrology Dialysis Transplantation 23 (1): 47-51. https://doi. org/10.1093/ndt/gfm517

Evans Braziel, Jana. 2001. "Sex and Fat Chics: Deterritorializing the Fat Female Body". Teoksessa Bodies Out of Bounds: Fatness and Transgression, toim. Jana Evansa Braziel ja Kathleen LeBesco, 231-256. Oakland, CA: University of California Press.

Frith, Simon. 1996. Performing Rites: Evaluating Popular Music. Oxford: Oxford University Press.

Ganetz, Hillevi. 2011. "Fame Factory: Performing Gender and Sexuality in Talent Reality Television". Culture Unbound: Journal of Current Cultural Research vol. 3: 401-417. https://doi.org/ 10.3384/cu.2000.1525.113401

Garland-Thomson, Rosemarie. 2001. "Seeing the Disabled: Visual Rhetorics of Disability in Popular Photography". Teoksessa The New Disability History: American Perspectives, toim. Paul K. Longmore \& Lauri Umansky, 335-374. New York: New York University Press.

Graham, Stephen. 2017. "The X Factor and Reality Television: Beyond Good and Evil". Popular Music 36 (1): 6-20. https://doi.org/ 10.1017/S0261143016000635

Grindstaff, Laura. 2002. The Money Shot: Trash, Class, and the Making of TV Talk Shows. Chicago: The University of Chicago Press.

Guarracino, Serena. 2010. "It's Not Over till the Fat Lady Sings: The Weight of the Opera Diva". Teoksessa Historicizing Fat in Anglo-American Culture, toim. Elena LevyNavarro, 192-212. Columbus: Ohio State University Press. https://doi.org/10.2307 i.ctv1725rd4

Harjunen, Hannele. 2006. "Käsityksiä lihavan naisen seksuaalisuudesta". Teoksessa Seksuaalinen ruumis, toim. Taina Kinnunen ja Anne Puuronen, 183-197. Helsinki: Gaudeamus.

Harjunen, Hannele. 2007. "Lihavuus välitilana". Teoksessa Koolla on väliä! Lihavuus, ruumisnormit ja sukupuoli, toim. Hannele Harjunen ja Katariina Kyrölä, 205-227. Helsinki: Like.

Harjunen, Hannele. 2017. Neoliberal Bodies and the Gendered Fat Body. New York: Routledge.

Harjunen, Hannele ja Katariina Kyrölä. 2007. ”Johdanto. Lihavuustutkimusta toisin". Teoksessa Koolla on väliä! Lihavuus, ruumisnormit ja sukupuoli, toim. Hannele Harjunen ja Katariina Kyrölä, 9-46. Helsinki: Like.

Hesmondhalgh, David ja Sarah Baker. 2008. "Creative Work and Emotional Labour in the Television Industry". Theory, Culture Eं Society 25 (7-8): 97-118. https://doi. org/10.1177/0263276408097798

Holmes, Su. 2004. "Reality Goes Pop! Reality TV, Popular Music, and Narratives of Stardom in Pop Idol". Television E New Media 5 (2): 147-172. https://doi.org/10.1177/15 27476403255833

Holmes, Su ja Deborah Jermyn. 2004. Understanding Reality Television. New York: Routledge. 
Jackson, A., P. Stanforth, J. Gagnon et al. 2002. "The Effect of Sex, Age and Race on Estimating Percentage Body Fat from Body Mass Index: The Heritage Family Study". International Journal of Obesity vol. 26: 789-796. https://doi.org/10.1038/sj.ijo.0802006

Jarman-Ivens, Freya. 2011. Queer Voices: Technologies, Vocalities, and the Musical Flaw. New York: Palgrave Macmillan.

Jones, Stefanie A. 2014. ”The Performance of Fat: The Spectre Outside the House of Desire". Teoksessa Queering Fat Embodiment, toim. Cat Pausé, Jackie Wykes ja Samantha Murray, 31-48. Farnham, Surrey: Ashgate.

Juntunen, Riikka. 2020. "Not the worthless person people think I am - lihavan naislaulajuuden affektiiviset esityksen musiikkireality-ohjelmissa". Pro gradu -tutkielma. Helsingin yliopisto.

Kent, Le'a. 2001. "Fighting Abjection: Representing Fat Women". Teoksessa Bodies out of Bounds: Fatness and Transgression, toim. Jana Evans Braziel ja Kathleen LeBesco, 130-150. Oakland, CA: University of California Press.

Klein, Richard. 2001. "Fat Beauty". Teoksessa Bodies out of Bounds: Fatness and Transgression, toim. Jana Evans Braziel ja Kathleen LeBesco, 19-38. Oakland, CA: University of California Press.

Kyrölä, Katariina. 2007. "Lihavuusvaara! Pelon politiikka ja lihava ruumiillisuus Helsingin Sanomissa". Teoksessa Koolla on väliä! Lihavuus, ruumisnormit ja sukupuoli, toim. Hannele Harjunen ja Katariina Kyrölä, 49-82. Helsinki: Like.

Kyrölä, Katariina. 2014. The Weight of Images: Affect, Body Image and Fat in the Media. New York: Routledge.

Meizel, Katherine L. 2011. Idolized: Music, Media, and Identity in American Idol. Bloomington: Indiana University Press.

Mendible, Myra. 2007. "Embodying Latinidad: An Overview". Teoksessa Bananas to Buttocks: The Latina Body in Popular Film and Culture, toim. Myra Mendible, 1-28. Austin: University of Texas Press.

Molinary, Rosie. 2007. Hijas Americanas: Beauty, Body Image, and Growing Up Latina. Emeryville, CA: Seal Press.

Neumark, Norie. 2010. "Introduction: The Paradox of Voice". Teoksessa Voice: Vocal Aesthetics in Digital Arts and Media, toim. Norie Neumark, Ross Gibson \& Theo van Leeuwen, xv-xxxiii. Cambridge, MA: The MIT Press.

NIH The National Institute of Diabetes and Digestive and Kidney Diseases. 2014. Overweight EO Obesity Statistics. Tark. 13.2.2021. https://www.niddk.nih.gov/health-information/health-statistics/overweight-obesity

Paasonen, Susanna. 2011. Carnal Resonance: Affect and Online Pornography. Cambridge, MA: The MIT Press.

Pausé, Cat, Jackie Wykes ja Samantha Murray. 2014. ”Introduction: Why Queering Fat Embodiment?" Teoksessa Queering Fat Embodiment, toim. Cat Pausé, Jackie Wykes ja Samantha Murray, 1-12. Farnham, Surrey: Ashgate.

Puuronen, Anne. 2007. "Puhetta 'läskistä' - bodyfitness-urheilijan, anorektikon ja viihdetaiteilijan näkemyksiä ruumiistaan". Teoksessa Koolla on väliä! Lihavuus, ruumisnormit ja sukupuoli, toim. Hannele Harjunen ja Katariina Kyrölä, 229-250. Helsinki: Like.

Pääkkölä, Anna-Elena. 2017. "Mahtava peräsin ja pulleat purjeet. Lihavuus, naiskuva ja seksuaalisuus kolmessa suomalaisessa populaarimusiikkikappaleessa". Etnomusikologian vuosikirja vol. 29, 1-26. https://doi.org/10.23985/evk.60926 
Pääkkölä, Anna-Elena. 2019. ”Nicki Minaj’s 'Anaconda': Intersectional Feminist Fat Studies, Sexuality, and Embodiment". Teoksessa The Bloomsbury Handbook of Popular Music Video Analysis, toim. Lori A. Burns ja Stan Hawkins, 361-379. New York: Bloomsbury.

Raisborough, Jayne. 2011. Lifestyle Media and the Formation of the Self. New York: Palgrave Macmillan.

Rautiainen-Keskustalo, Tarja. 2013. "Paikalliset ja globaalit skenet - medioitunut musiikkikulttuuri tutkimuskohteena". Teoksessa Musiikki kulttuurina, toim. Pirkko Moisala ja Elina Seye, 321-336. Helsinki: Suomen etnomusikologinen seura.

Rey, Mario. 2018. "When the Bearded Lady Sings: Ambiguity Aesthetics, Queer Identity, and the Gendering of Presentational Voice". Teoksessa Rethinking Difference in Gender, Sexuality, and Popular Music: Theory and Politics of Ambiguity, toim. Gavin Lee, 24-42. New York: Routledge.

Richardson, John. 2012. An Eye for Music. New York: Oxford University Press.

Riihimäki, Hanna-Mari ja Anna-Elena Pääkkölä. 2020. ”Alternative Femininities, Voices, and Queer Body Politics in Alma's 'Dye My Hair". Teoksessa Made in Finland: Studies in Popular Music, toim. Toni-Matti Karjalainen ja Kimi Kärki, 187-199. Milton: Taylor and Francis. https://doi.org/10.4324/9780429277429

Rohrleitner, Marion Christina. 2016. "Conspicuous Consumption? Eating Disorders as Nervous Immigrant Conditions in Contemporary Latina Fiction". Teoksessa Latin@s' Presence in the Food Industry, toim. Meredith E. Abarca ja Consuelo Carr Salas, 167-184. Fayetteville: University of Arkansas Press.

Sastre, Alexandra. 2014. "Towards a Radical Body Positive". Feminist Media Studies 14 (6): 929-943. https://doi.org/10.1080/14680777.2014.883420

Senyonga, Mary ja Caleb Luna. 2021. "'If I'm Shinin', Everybody Gonna Shine’: Centering Black Fat Women and Femmes within Body and Fat Positivity". Fat Studies. https:// doi.org/10.1080/21604851.2021.1907112

Skeggs, Beverley ja Helen Wood. 2012. Reacting to Reality Television: Performance, Audience and Value. New York: Routledge. https://doi.org/10.4324/9780203144237

Solovay, Sondra ja Esther Rothblum. 2009. "Introduction”. Teoksessa The Fat Studies Reader, toim. Sondra Solovay ja Esther Rothblum, 1-8. New York: New York University Press.

Strings, Sabrina. 2019. Fearing the Black Body. The Racial Origins of Fat Phobia. New York: New York University Press.

Syco Entertainment. 2020. About Us. Tark. 29.5.2021. https://www.sycoentertainment.com.

Tarvainen, Anne. 2012. Laulajan ääni ja ilmaisu. Kehollinen lähestymistapa laulajan kuuntelemiseen, esimerkkinä Björk. Tampere: Tampere University Press.

Tarvainen, Anne. 2018. "Democratizing Singing: Somaesthetic Reflections on Vocality, Deaf Voices, and Listening". Pragmatism Today 9 (1): 91-108.

Tiainen, Milla. 2013. "Revisiting the Voice in Media and as Medium: New Materialist Propositions". NECSUS 2 (2): 383-406. https://doi.org/ 10.5117/NECSUS2013.2.TIAI

WHO World Health Organization. 2020. Overweight. Tark. 29.5.2021. https://gateway.euro.who.int/en/indicators/h2020 6-overweight,

Wilkes, Neil. 2009. "Huge Audiences for 'Talent', 'Who"'. Digital Spy 12.4.2009. Tark. 29.5.2021. https://www.digitalspy.com/tv/ratings/a152472/huge-audiences-for-talent-who,

Wolf, Stacy. 2011. Changed for Good: A Feminist History of the Broadway Musical. New York: Oxford University Press. 